\title{
The effect of selective cerebral perfusion on cerebral versus somatic tissue oxygenation during aortic coarctation repair in neonates and infants
}

Li Zhang ${ }^{1}$, Lu Liu' ${ }^{1}$, Zhiqiu Zhong ${ }^{1}$, Hengfang Jin ${ }^{1}$, Jian Jia ${ }^{1}$, Lingzhong Meng ${ }^{2^{*}}$, Xuming Mo $^{3^{*}}$ and Xiaohua Shi ${ }^{\text {* }^{*}}$

\begin{abstract}
Background: Suboptimal tissue perfusion and oxygenation may be the root cause of certain perioperative complications in neonates and infants having complicated aortic coarctation repair. Practical, effective, and real-time monitoring of organ perfusion and/or tissue oxygenation may provide early warning of end-organ mal-perfusion.

Methods: Neonates/infants who were scheduled for aortic coarctation repair with cardiopulmonary bypass (CPB) and selective cerebral perfusion (SCP) from January 2015 to February 2017 in Children's Hospital of Nanjing Medical University participated in this prospective observational study. Cerebral and somatic tissue oxygen saturation $\left(\mathrm{SctO}_{2}\right.$ and $\mathrm{SstO}_{2}$ ) were monitored on the forehead and at the thoracolumbar paraspinal region, respectively. $\mathrm{SctO}_{2}$ and $\mathrm{SstO}_{2}$ were recorded at different time points (baseline, skin incision, CPB start, SCP start, SCP end, aortic opening, CPB end, and surgery end). $\mathrm{SctO}_{2}$ and $\mathrm{SstO}_{2}$ were correlated with mean arterial pressure (MAP) and partial pressure of arterial blood carbon dioxide $\left(\mathrm{PaCO}_{2}\right)$.

Results: Data of 21 patients were analyzed (age $=75 \pm 67$ days, body weight $=4.4 \pm 1.0 \mathrm{~kg}$ ). $\mathrm{SstO}_{2}$ was significantly lower than $\mathrm{SctO}_{2}$ before aortic opening and significantly higher than $\mathrm{SctO}_{2}$ after aortic opening. $\mathrm{SstO}_{2}$ correlated with leg MAP when the measurements during SCP were $(r=0.67, p<0.0001)$ and were not included $(r=0.46, p<0.0001)$; in contrast, $\mathrm{SctO}_{2}$ correlated with arm MAP only when the measurements during SCP were excluded $(r=0.14, p=0.08$ vs. $r=0.66, p<0.0001)$. SCP also confounded $\mathrm{SctO}_{2} / \mathrm{SstO}_{2}$ 's correlation with $\mathrm{PaCO}_{2} ;$ when the measurements during SCP were excluded, $\mathrm{SctO}_{2}$ positively correlated with $\mathrm{PaCO}_{2}(r=0.65, p<0.0001)$, while $\mathrm{SstO}_{2}$ negatively correlated with $\mathrm{PaCO}_{2}(r=-0.53, p<0.0001)$.

Conclusions: $\mathrm{SctO}_{2}$ and $\mathrm{SstO}_{2}$ have distinct patterns of changes before and after aortic opening during neonate/ infant aortic coarctation repair. $\mathrm{SctO}_{2} / \mathrm{SstO}_{2}$ 's correlations with MAP and $\mathrm{PaCO}_{2}$ are confounded by SCP. The outcome impact of combined $\mathrm{SctO}_{2} / \mathrm{SstO}_{2}$ monitoring remains to be studied.
\end{abstract}

\footnotetext{
*Correspondence: lingzhong.meng@yale.edu; mohsuming15@njmu.edu.cn; relax_2024@163.com

1 Department of Anesthesiology, Children's Hospital of Nanjing Medical

University, 210008, Nanjing, Jiangsu Province, China

2 Department of Anesthesiology, Yale University School of Medicine,

06520 New Haven, CT, USA

${ }^{3}$ Department of Cardiothoracic, Children's Hospital of Nanjing Medical

University, 210008 Nanjing, Jiangsu Province, China
}

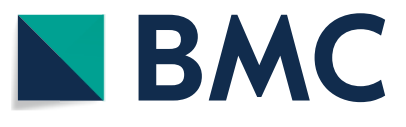

(c) The Author(s) 2021. Open Access This article is licensed under a Creative Commons Attribution 4.0 International License, which permits use, sharing, adaptation, distribution and reproduction in any medium or format, as long as you give appropriate credit to the original author(s) and the source, provide a link to the Creative Commons licence, and indicate if changes were made. The images or other third party material in this article are included in the article's Creative Commons licence, unless indicated otherwise in a credit line to the material. If material is not included in the article's Creative Commons licence and your intended use is not permitted by statutory regulation or exceeds the permitted use, you will need to obtain permission directly from the copyright holder. To view a copy of this licence, visit http://creativecommons.org/licenses/by/4.0/. The Creative Commons Public Domain Dedication waiver (http://creativeco mmons.org/publicdomain/zero/1.0/) applies to the data made available in this article, unless otherwise stated in a credit line to the data. 
Keywords: Neonates and infants, Aortic coarctation repair, Cerebral tissue oxygen saturation, Somatic tissue oxygen saturation, prospective cohort study

\section{Introduction}

Coarctation of the aorta $(\mathrm{CoA})$ is a congenital narrowing of upper descending thoracic aorta adjacent to the site of attachment of ductus arteriosus just distal to the left subclavian artery. The reported prevalence of $\mathrm{CoA}$ is approximately 4 per 10,000 live births $[1,2]$ or 400 per million live births, [3] which accounts for $\sim 4 \%$ of all congenital heart defects [3]. The preferred treatment for native CoA during childhood is surgical correction based on the considerations related to midterm and long-term outcomes in many children's hospitals $[4,5]$. The optimal age for elective repair of aortic coarctation is controversial. Some centers perform elective aortic coarctation repair around 1.5 years of age [6]. However, surgery at a much earlier age may be required depending on the severity of the coarctation and the adequacy of the collateral flow.

CoA does not cause hemodynamic problems in utero, as two-thirds of the combined cardiac output flows through the patent ductus arteriosus (PDA) into the descending thoracic aorta, bypassing the site of constriction at the isthmus. During the neonatal period, when the PDA and foramen ovale begin to close, the cardiac output that must cross the narrowed aortic segment to reach the lower extremities steadily increases and the clinical consequences start to show. The central dilemma of this unique congenital malformation is the divergent hemodynamic patterns in the body parts that are perfused by the vasculature proximal and distal to the coarctation, respectively, i.e., systolic hypertension in the upper extremities while hypotension in the lower extremities.

CoA repair in small children has inherent risks [7]. The operative death in children less than one-year-old can be as high as $\sim 40 \%$, albeit that in children older than one year is much less $(\sim 0.4 \%) .^{7}$ Suboptimal organ perfusion and tissue oxygenation as a result of cardiovascular malformation, cardiopulmonary bypass (CPB), deep hypothermic circulatory arrest, and selective cerebral perfusion (SCP) may be among the root causes of endorgan injuries in this patient population. The ability to monitor real-time organ/tissue perfusion and oxygenation can facilitate intraoperative management and reduce complications.

A tissue oximeter based on near-infrared spectroscopy (NIRS) can non-invasively and continuously measure the hemoglobin saturation of the mixed arterial, capillary, and venous blood in the tissue bed that is about 1-2.5 cm underneath the sensor [8]. Cerebral tissue oxygen saturation $\left(\mathrm{SctO}_{2}\right)$ is measured with the sensor placed on the forehead, while somatic tissue oxygen saturation $\left(\mathrm{SstO}_{2}\right)$ is measured with the sensor positioned at a peripheral location. NIRS-measured tissue oxygenation is determined by the balance between tissue oxygen consumption and supply; when tissue oxygen consumption remains relatively stable, it is essentially determined by tissue perfusion or oxygen delivery [9].

We hypothesize that tissue beds perfused by the vasculature proximal and distal to the aortic coarctation have distinct oxygenation patterns during aortic coarctation surgery in neonates and infants. This study aims to compare $\mathrm{SctO}_{2}$ and $\mathrm{SstO}_{2}$ monitored on the forehead and at the paraspinal thoracolumbar region, respectively, and correlate $\mathrm{SctO}_{2} / \mathrm{SstO}_{2}$ with relevant physiological variables.

\section{Methods}

This prospective cohort study was approved by the Internal Review Board at Children's Hospital of Nanjing Medical University located in Nanjing, Jiangsu Province, China. Consent for study participation was obtained from the patient's guardians before surgery.

\section{Patients}

Neonates and infants undergoing complicated aortic coarctation repair surgery from January 2015 to February 2017 in the Children's Hospital of Nanjing Medical University participated in this study. The inclusion criteria were age $<1$-year-old and coarctation surgery mandating $\mathrm{CPB}$ and SCP. The exclusion criteria were emergent surgery and refusal by the patient's guardians.

\section{Anesthesia}

After arriving in the operating room, patients were first sedated using intravenous fentanyl $(2 \mathrm{mcg} / \mathrm{kg})$ and midazolam $(0.05 \mathrm{mg} / \mathrm{kg})$. Standard electrocardiography, pulse oximetry, and non-invasive blood pressure monitoring, in addition to $\mathrm{SctO}_{2} / \mathrm{SstO}_{2}$ monitoring, were applied before anesthesia induction. Anesthesia was induced using intravenous administration of penehyclidine $(0.01 \mathrm{mg} / \mathrm{kg})$, fentanyl $(10 \mathrm{mcg} / \mathrm{kg})$, midazolam $(0.1 \mathrm{mg} /$ $\mathrm{kg})$, and rocuronium bromide $(0.6 \mathrm{mg} / \mathrm{kg})$. All patients were intubated and mechanically ventilated with a tidal volume of $6-8 \mathrm{ml} / \mathrm{kg}$, inspiratory to expiratory time ratio of $1: 1.5-2$, and inspired oxygen of $40 \%$. The respiratory rate was adjusted per the level of end-tidal carbon dioxide which was maintained at $45-50 \mathrm{mmHg}$ before $\mathrm{CPB}$ in patients with preductal patent ductus arteriosus. An 
arterial catheter (22-24 GA) was placed in the right radial and femoral arteries to monitor the arterial blood pressure on the right arm and right leg, respectively. A central venous catheter $(5 \mathrm{~F})$ was placed through the right jugular vein for intravenous access and central venous pressure monitoring. Anesthesia was maintained using sevoflurane inhalation and intravenous infusion of rocuronium bromide $(0.1 \mathrm{mg} / \mathrm{kg} / \mathrm{h})$, in addition to the intermittent intravenous bolus of fentanyl $(10 \sim 20 \mathrm{mcg} / \mathrm{kg})$, and midazolam $(0.1 \mathrm{mg} / \mathrm{kg})$.

\section{Tissue Oxygenation Monitoring}

$\mathrm{SctO}_{2}$ and $\mathrm{SstO}_{2}$ were monitored by a tissue oximeter (CASMED MC-2030 C, CAS Medical System, Branford, $\mathrm{CT}) . \mathrm{SctO}_{2}$ was monitored with the pediatric sensor placed on the right forehead, while $\mathrm{SstO}_{2}$ was monitored with the pediatric sensor placed on the right paraspinal muscle at the $\mathrm{T}_{10}-\mathrm{L}_{2}$ level. The first set of $\mathrm{SctO}_{2}$ and $\mathrm{SstO}_{2}$ measurements were obtained with the patient sedated but spontaneously breathing (i.e., before anesthesia induction). SctO $\mathrm{St}_{2}$ and $\mathrm{SstO}_{2}$ were then measured at the pre-determined time points throughout the surgery.

\section{Surgery}

A midline sternal incision was made for access. The ascending aorta and superior and inferior vena cava were cannulated in 20 patients. One patient with an interrupted aortic arch received additional pulmonary artery cannulation. Following heparinization, CPB was established using an artificial heart-lung machine (Maquet $\mathrm{HL}$ 20, MAQUET Cardiovascular, LLC, Wayne, NJ, USA) with a membrane oxygenator (D901, Sorin Group Italia S.r.I., Mirandola, Italy). The CPB started with moderate to low temperature $\left(24-28^{\circ} \mathrm{C}\right)$ and moderate to high flow rate $(100-150 \mathrm{ml} / \mathrm{kg} / \mathrm{min})$. Following the clamping of the aorta and superior and inferior vena cava, the heart was arrested using histidine-tryptophan-ketoglutarate solution (Dr. Franz Köhler Chemie GmbH, Bensheim, Germany) infused at the aortic root. Following the correction of intracardiac malformation, the rectal temperature was further decreased to $18-20{ }^{\circ} \mathrm{C}$ for aortic arch repair. SCP was accomplished following the advancement of the aortic cannula into the innominate artery with a flow rate of $20-40 \mathrm{ml} / \mathrm{kg} / \mathrm{min}$. The successful coarctation repair was followed by aorta re-opening and then the termination of CPB. Patients were mildly hyperventilated, and the hemodynamics were normally supported using epinephrine $0.05-0.1 \mathrm{mcg} / \mathrm{kg} / \mathrm{min}$ and milrinone $0.5 \mathrm{mcg} / \mathrm{kg} / \mathrm{min}$.

\section{Data Collection}

Physiological measurements including mean arterial pressure (MAP), partial pressure of arterial blood carbon dioxide $\left(\mathrm{PaCO}_{2}\right)$, hematocrit, temperature, arterial blood oxygen saturation $\left(\mathrm{SaO}_{2}\right)$, mixed venous blood oxygen saturation $\left(\mathrm{SmvO}_{2}\right), \mathrm{SctO}_{2}$ and $\mathrm{SstO}_{2}$ were prospectively recorded at the pre-determined time points. These time points were baseline with the patient sedated and spontaneously breathing, skin incision, CPB start, SCP start, $\mathrm{SCP}$ end, aortic opening, $\mathrm{CPB}$ end, and surgery end. $1 \mathrm{ml}$ of arterial blood and $1 \mathrm{ml}$ of mixed venous blood were taken for blood gas analysis at each time point.

\section{Statistical Analysis}

Data were presented in mean \pm SD. The difference between two variables at different time points was assessed using paired t-test. Pearson's correlation coefficient was used to assess the correlation between different variables. A two-sided $\mathrm{p}$-value $<0.05$ was regarded as statistically significant.

\section{Results}

Among the 21 patients who participated in this study, 16 were males, 3 neonates ( $<30$ days old), and 18 infants $(<$ 1 -year-old). The average age was $75 \pm 67$ days (range $=$ 12 to 333 days). The average body weight was $4.4 \pm 1.0 \mathrm{~kg}$ (range $=2.8$ to $6.5 \mathrm{~kg})$ (Table 1$)$. All patients had ventricular septal defect; 20 patients had patent ductus arteriosus; 16 had pulmonary hypertension; and 9 had an atrial septal defect.

The CPB, aortic clamping, and SCP time were $185 \pm$ $101 \mathrm{~min}, 68 \pm 17 \mathrm{~min}$, and $23 \pm 6 \mathrm{~min}$, respectively. The length of hospital stay, ICU stay, and postoperative intubation time was $25 \pm 8$ days, $11 \pm 2$ days, and $6 \pm 1$ days, respectively.

The physiological measurements at different time points are presented in Table 2. $\mathrm{SstO}_{2}$ was consistently and significantly lower than $\mathrm{SctO}_{2}$ at each time points before the aortic opening, including the baseline $(\Delta \approx-12 \%)$, skin incision $(\Delta \approx-12 \%)$, CPB start $(\Delta \approx$ $-12 \%)$, SCP start $(\Delta \approx-40 \%)$, and SCP end $(\Delta \approx-21 \%)$ $\left(\Delta=\mathrm{SstO}_{2}-\mathrm{SctO}_{2}\right)$. Following the aortic opening, this relationship was reversed with the $\mathrm{SstO}_{2}$ consistently and significantly higher than $\mathrm{SctO}_{2}$ at each time point, including aortic opening $(\Delta \approx+24 \%)$, CPB end $(\Delta \approx$ $+12 \%)$, and surgery end $(\Delta \approx+8 \%)$. Overall, $\mathrm{SctO}_{2}$ and $\mathrm{SstO}_{2}$ were significantly correlated $(r=-0.57, p<0.0001$, Fig. $1 \mathrm{~A}$ ); however, the correlation became weaker after exclusion of the measurements during SCP $(r=-0.22$, $p=0.01$, Fig. 1B). The correlation between $\mathrm{SctO}_{2}$ and $\mathrm{SstO}_{2}$ was at its strongest when only considering the data before SCP $(r=0.81, p<0.0001$, Fig. $1 \mathrm{C})$ and weakest when only considering the data after SCP $(r=0.009, p=$ 0.94, Fig. 1D).

The correlation between $\mathrm{SctO}_{2}$ and $\mathrm{SmvO}_{2}$ was stronger than that between $\mathrm{SstO}_{2}$ and $\mathrm{SmvO}_{2} \cdot \mathrm{SctO}_{2}$ was significantly correlated with $\mathrm{SmvO}_{2}$ with the 
Table 1 Patient demographics

\begin{tabular}{|c|c|c|c|c|c|c|c|c|c|}
\hline Patient \# & Gender & Age (Day) & Weight (kg) & PDA & VSD & ASD & $\begin{array}{l}\text { Pulmonary } \\
\text { hypertension }\end{array}$ & Others & ASA Grade \\
\hline 1 & Female & 79 & 3.7 & Y & Y & Y & Y & Aortic arch hypogenesis & III \\
\hline 2 & Male & 26 & 2.8 & Y & Y & Y & $\mathrm{N}$ & Aortic arch hypogenesis & III \\
\hline 3 & Male & 50 & 3.8 & Y & Y & Y & Y & Aortic arch hypogenesis & IV \\
\hline 4 & Male & 141 & 6 & Y & Y & N & Y & & III \\
\hline 5 & Female & 38 & 2.8 & Y & Y & Y & Y & Aortic arch hypogenesis & IV \\
\hline 6 & Male & 22 & 3.8 & Y & Y & Y & Y & Respiratory failure & IV \\
\hline 7 & Female & 74 & 5 & Y & Y & N & Y & & III \\
\hline 8 & Male & 71 & 4.5 & Y & Y & N & Y & & III \\
\hline 9 & Male & 41 & 4.5 & Y & Y & N & Y & $\begin{array}{l}\text { Patent foramen ovale Mitral and tricuspid insuf- } \\
\text { ficiency }\end{array}$ & IV \\
\hline 10 & Female & 98 & 4.7 & Y & Y & Y & Y & & IV \\
\hline 11 & Female & 333 & 6.5 & Y & Y & N & Y & & IV \\
\hline 12 & Male & 46 & 3.5 & Y & Y & Y & N & & IV \\
\hline 13 & Male & 47 & 2.8 & Y & Y & N & Y & Patent foramen ovale & III \\
\hline 14 & Male & 83 & 4.9 & Y & Y & $\mathrm{N}$ & Y & & III \\
\hline 15 & Male & 53 & 4 & Y & Y & $\mathrm{N}$ & Y & & III \\
\hline 16 & Male & 120 & 5.6 & Y & Y & $\mathrm{N}$ & $\mathrm{N}$ & & III \\
\hline 17 & Male & 92 & 5.9 & Y & Y & $\mathrm{N}$ & $\mathrm{N}$ & Patent foramen ovale & III \\
\hline 18 & Male & 52 & 4.5 & Y & Y & $\mathrm{N}$ & Y & Taussig-Bing anomaly & IV \\
\hline 19 & Male & 12 & 4 & Y & Y & Y & $\mathrm{N}$ & & III \\
\hline 20 & Male & 49 & 4.9 & Y & Y & $\mathrm{N}$ & Y & Patent foramen ovale, anomalous coronary origin & IV \\
\hline 21 & Male & 48 & 4.5 & N & Y & Y & Y & Interrupted Aortic Arch Rh hemolytic disease & IV \\
\hline
\end{tabular}

$\mathrm{PDA}=$ patent ductus arteriosus; $\mathrm{VSD}=$ ventricular septal defect; $\mathrm{ASD}=$ atrial septal defect; $\mathrm{ASA}=$ American Society of Anesthesiologists; $\mathrm{Y}=$ yes; $\mathrm{N}=$ no

Table 2 Physiological variables measured at different time points

\begin{tabular}{|c|c|c|c|c|c|c|c|c|}
\hline Variable (unit) & Baseline $^{a}$ & Skin incision & CPB start & SCP start & SCP stop & Aorta open & CPB stop & Surgery end \\
\hline $\mathrm{SctO}_{2}(\%)$ & $70.3 \pm 3.5$ & $67.6 \pm 3.5$ & $58.6 \pm 3.5$ & $79.6 \pm 4.0$ & $71.8 \pm 2.5$ & $51.8 \pm 2.3$ & $59.0 \pm 2.8$ & $61.3 \pm 6.0$ \\
\hline $\mathrm{SstO}_{2}(\%)$ & $58.8 \pm 5.8$ & $55.1 \pm 6.2$ & $46.4 \pm 6.7$ & $39.6 \pm 5.2$ & $50.5 \pm 4.9$ & $75.8 \pm 4.4$ & $70.5 \pm 2.3$ & $69.5 \pm 6.2$ \\
\hline $\mathrm{SaO}_{2}(\%)$ & $99.6 \pm 0.4$ & $99.6 \pm 0.4$ & $99.6 \pm 0.4$ & $99.8 \pm 0.2$ & $99.9 \pm 0.1$ & $99.6 \pm 0.4$ & $99.5 \pm 0.4$ & $99.4 \pm 0.6$ \\
\hline $\mathrm{SmvO}_{2}(\%)$ & $70.7 \pm 5.7$ & $68.4 \pm 5.2$ & $56.4 \pm 5.0$ & $78.3 \pm 4.0$ & $74.4 \pm 3.4$ & $58.5 \pm 7.8$ & $60.3 \pm 5.7$ & $62.3 \pm 9.1$ \\
\hline MAP-arm (mmHg) & $65.9 \pm 3.8$ & $63.4 \pm 3.0$ & $56.4 \pm 3.4$ & $57.6 \pm 4.5$ & $54.1 \pm 2.5$ & $57.3 \pm 4.1$ & $60.2 \pm 3.9$ & $59.9 \pm 5.1$ \\
\hline MAP-leg (mmHg) & $44.2 \pm 8.5$ & $42.4 \pm 7.7$ & $38.7 \pm 6.7$ & $22.1 \pm 4.8$ & $28.1 \pm 9.5$ & $45.2 \pm 9.5$ & $48.5 \pm 9.6$ & $50.7 \pm 10.7$ \\
\hline $\mathrm{PaCO}_{2}(\mathrm{mmHg})$ & $45.3 \pm 3.8$ & $42.4 \pm 3.4$ & $38.9 \pm 2.6$ & $31.2 \pm 1.8$ & $29.7 \pm 1.2$ & $31.6 \pm 1.5$ & $35.1 \pm 3.5$ & $37.9 \pm 3.1$ \\
\hline Hematocrit (\%) & $38.3 \pm 2.1$ & $38.0 \pm 2.2$ & $37.2 \pm 2.1$ & $21.0 \pm 1.8$ & $20.6 \pm 2.7$ & $25.1 \pm 1.8$ & $28.7 \pm 1.6$ & $34.3 \pm 1.5$ \\
\hline Temperature $\left({ }^{\circ} \mathrm{C}\right)$ & $37.0 \pm 0.5$ & $36.6 \pm 0.4$ & $36.2 \pm 0.4$ & $20.1 \pm 1.2$ & $19.6 \pm 1.2$ & $28.6 \pm 2.6$ & $36.5 \pm 0.5$ & $36.1 \pm 0.5$ \\
\hline Lactate (mmol/l) & $1.3 \pm 0.2$ & $1.3 \pm 0.3$ & $1.6 \pm 0.3$ & $2.5 \pm 0.3$ & $3.7 \pm 0.4$ & $3.1 \pm 0.3$ & $2.6 \pm 0.3$ & $2.5 \pm 0.4$ \\
\hline
\end{tabular}

${ }^{a}$ with patient sedated using small dose of fentanyl and midazolam and spontaneously breathing room air

$\mathrm{CPB}=$ cardiopulmonary bypass; $\mathrm{SCP}=$ selective cerebral perfusion; $\mathrm{SctO}_{2}=$ cerebral tissue oxygen saturation; $\mathrm{SstO}_{2}=$ somatic tissue oxygen saturation; $\mathrm{SaO}{ }_{2}=$ arterial blood oxygen saturation; $\mathrm{SmvO}_{2}=$ mixed venous blood oxygen saturation; MAP-arm = mean arterial pressure measured on arm; $\mathrm{MAP}$-leg = mean arterial pressure measured on leg; $\mathrm{PaCO}_{2}=$ arterial blood carbon dioxide partial pressure

measurements during SCP considered $(r=0.80, p<$ 0.0001 , Fig. $2 \mathrm{~A})$ and not considered $(r=0.69, p<0.0001$, Fig. 2B). $\mathrm{SstO}_{2}$ and $\mathrm{SmvO}_{2}$ were significantly correlated only when the measurements during SCP included $(r=$ $-0.35, p<0.0001$, Fig. 2 C), not excluded $(r=0.06, p=$ 0.54, Fig. 2D).
$\mathrm{SctO}_{2}$ and MAP measured on the arm were not correlated with all measurements considered $(r=0.14, p=$ 0.08 , Fig. $3 \mathrm{~A}$ ); however, they became significantly correlated with the measurements during $\mathrm{SCP}$ excluded $(r$ $=0.66, p<0.0001$, Fig. 3B). In contrast, $\mathrm{SstO}_{2}$ and $\mathrm{MAP}$ measured on the leg were significantly correlated with 

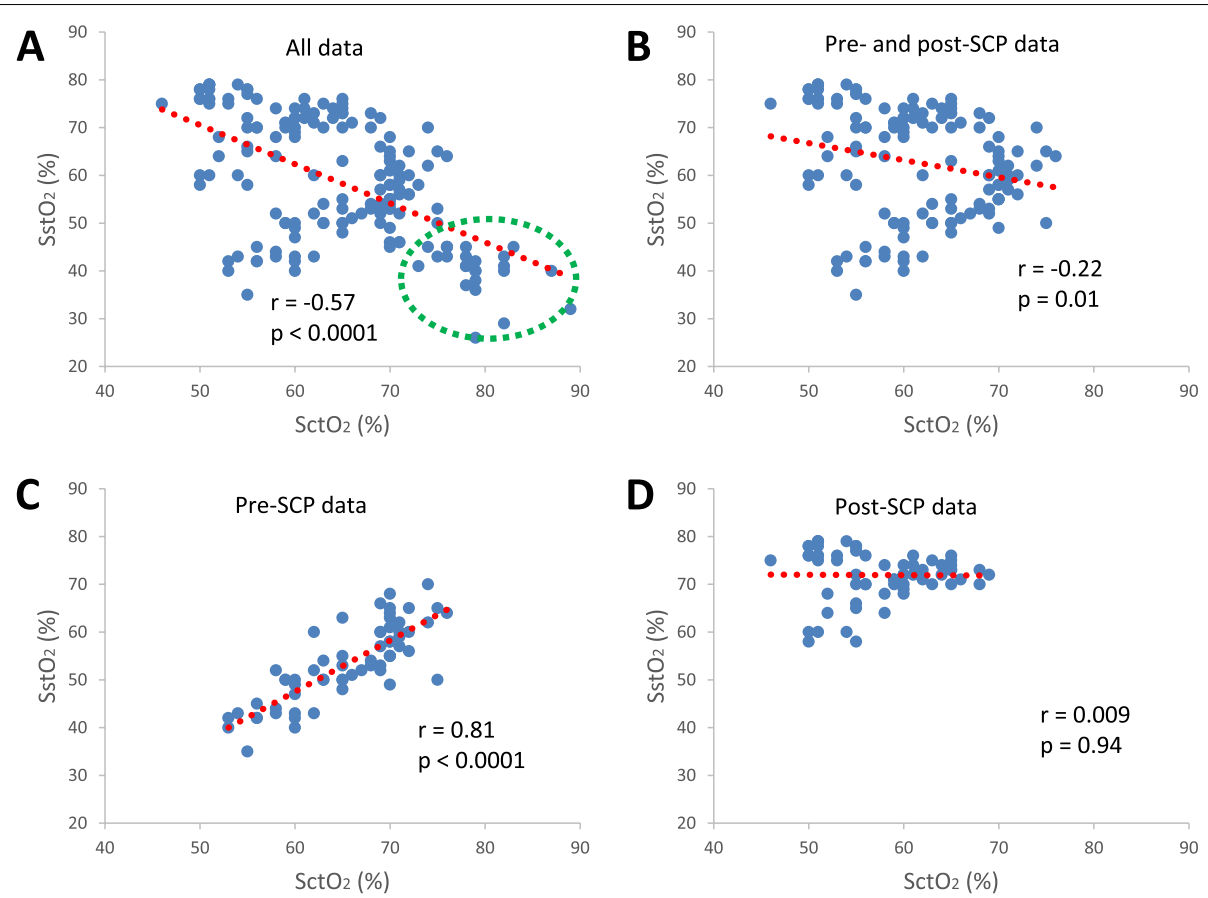

Fig. 1 Correlations between cerebral tissue oxygen saturation $\left(\mathrm{SctO}_{2}\right)$ and somatic tissue oxygen saturation $\left(\mathrm{SstO}_{2}\right)$. Thecorrelations were based on all data (A), data with the measurements duringselective cerebral perfusion (SCP) excluded (B), only data before SCP (C), and only data after SCP (D),respectively. The red dotted lines are trend lines and the data points in greendotted circle are measurements during SCP

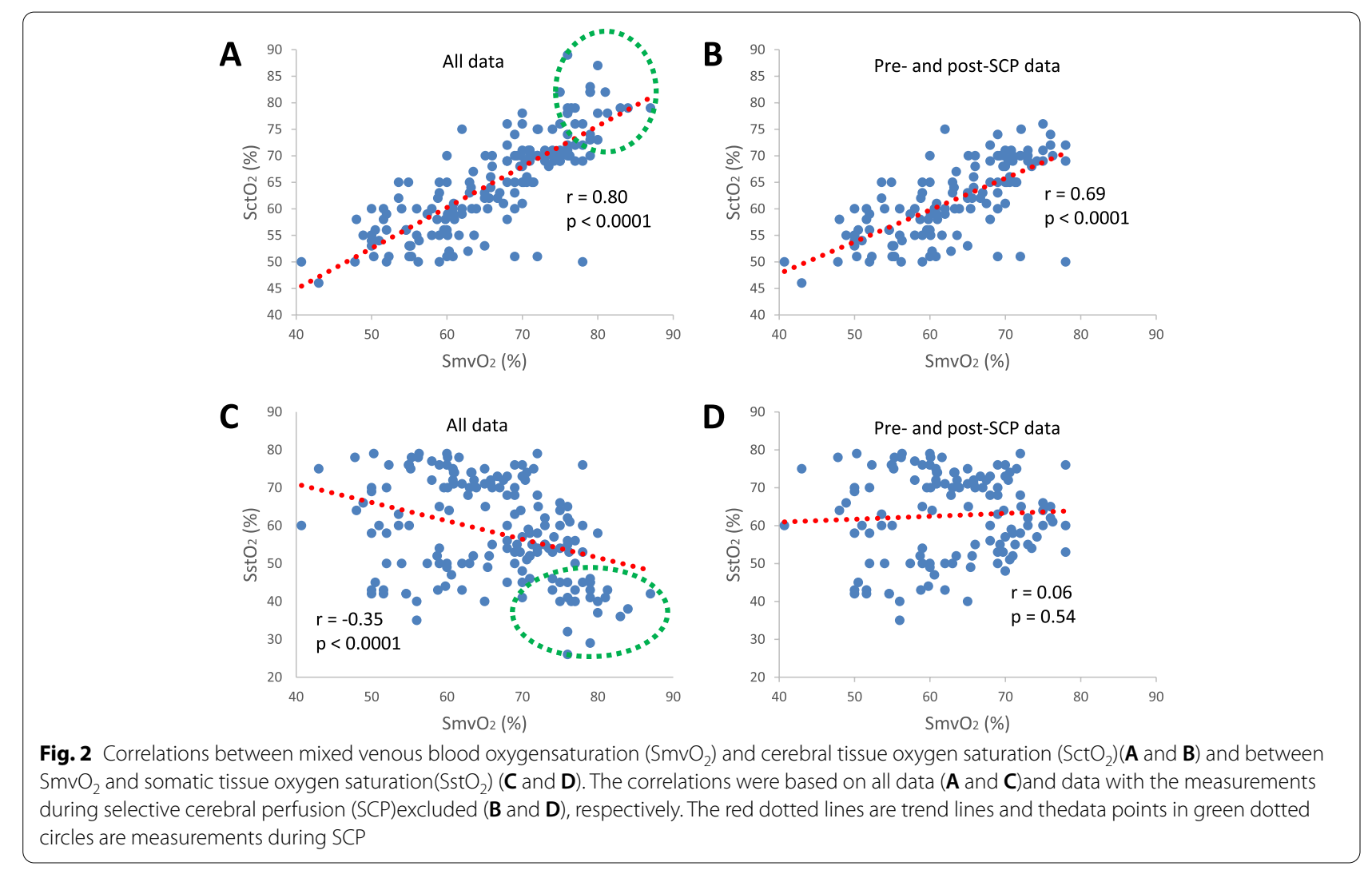



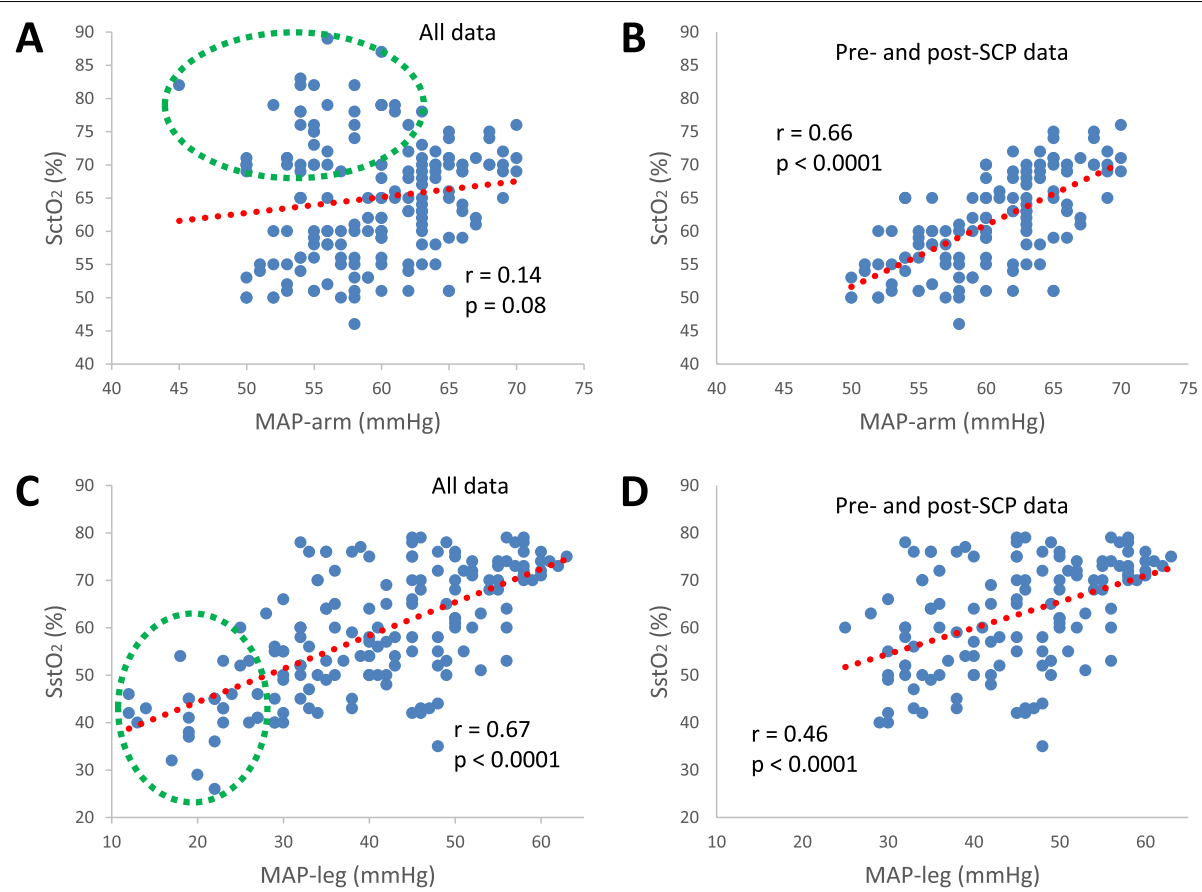

Fig. 3 Correlations between mean arterial pressure measuredon arm (MAP-arm) and cerebral tissue oxygen saturation $\left(\mathrm{SctO}_{2}\right)(\mathbf{A} a n d \mathbf{B})$ and between mean arterial pressure measured on leg (MAP-leg) and somatictissue oxygen saturation $\left(\mathrm{SstO}_{2}\right)(\mathbf{C}$ and $\mathbf{D})$. The correlations werebased on all data (A and $\mathbf{C}$ ) and data with the measurements during selectivecerebral perfusion (SCP) excluded (B and $\mathbf{D})$, respectively. The red dotted linesare trend lines and the data points in green dotted circles are measurementsduring SCP

measurements during SCP included $(r=0.67, p<0.0001$, Fig. $3 \mathrm{C}$ ) and excluded ( $r=0.46, p<0.0001$, Fig. 3D).

$\mathrm{SctO}_{2}$ and $\mathrm{PaCO}_{2}$ were not correlated with all measurements considered ( $r=-0.04, p=0.63$, Fig. 4 A); however, they became significantly correlated with the measurements during SCP excluded $(r=0.65, p<0.0001$, Fig. 4B). $\mathrm{SstO}_{2}$ and $\mathrm{PaCO}_{2}$ were also not correlated with all measurements considered ( $r=0.02, p=0.83$, Fig. $4 \mathrm{C}$ ); however, they also became significantly correlated with the measurements during SCP excluded $(r=-0.53, p<$ 0.0001, Fig. 4D). Of note, $\mathrm{SctO}_{2}$ positively (Fig. 4B), while $\mathrm{SstO}_{2}$ negatively (Fig. 4D), correlated with $\mathrm{PaCO}_{2}$ after the exclusion of the measurements during SCP.

\section{Discussion}

Our study showed that the measurements of $\mathrm{SctO}_{2}$ and $\mathrm{SstO}_{2}$ is surgical stage-dependent in neonates and infants undergoing aortic coarctation repair. $\mathrm{SstO}_{2}$ was significantly lower than $\mathrm{SctO}_{2}$ before aortic opening; however, following aortic opening, $\mathrm{SstO}_{2}$ was significantly higher than SctO2. SctO ${ }_{2}$ and $\mathrm{SstO}_{2}$ have distinct correlations with $\mathrm{MAP}, \mathrm{PaCO}_{2}$, hematocrit, and temperature. $\mathrm{SstO}_{2}$ consistently correlates with leg MAP; however, the correlation between $\mathrm{SctO}_{2}$ and arm MAP is confounded by the measurements during SCP. The measurements during SCP also confound the correlations between $\mathrm{SctO}_{2}$ and
$\mathrm{PaCO}_{2}$ and between $\mathrm{SstO}_{2}$ and $\mathrm{PaCO}_{2} . \mathrm{SctO}_{2}$, not $\mathrm{SstO}_{2}$, is significantly correlated with $\mathrm{SmvO}_{2}$.

Aortic cross-clamping is a well-known risk factor for cerebral, spinal cord, pulmonary, renal, and visceral injuries [10-12]. The disturbance of systemic and regional blood flow threatens organ perfusion, with the resultant tissue hypoperfusion and overzealous perfusion likely being the root cause of certain perioperative complications. Practical, effective, and real-time monitoring of organ perfusion and/or tissue oxygenation may provide early warning of end-organ mal-perfusion and thereby improve patient outcomes.

Tissue NIRS was originally used to monitor cerebral tissue bed. The recent technological advancement made the monitoring of non-cerebral tissue beds possible [8]. The combined monitoring of both cerebral and noncerebral tissue beds has the potential to further improve outcomes because the brain and non-brain organs have different schemes of metabolic demands and compensatory mechanisms during hemodynamic instability. Hoffman et al. pioneered the clinical application of multisite tissue oxygenation monitoring in pediatric cardiac patients. They monitored both cerebral oxygenation and renal oxygenation (with the sensor placed over the kidney region) in neonates undergoing stage 1 palliation for hypoplastic left heart syndrome [13]. Berens et al. 

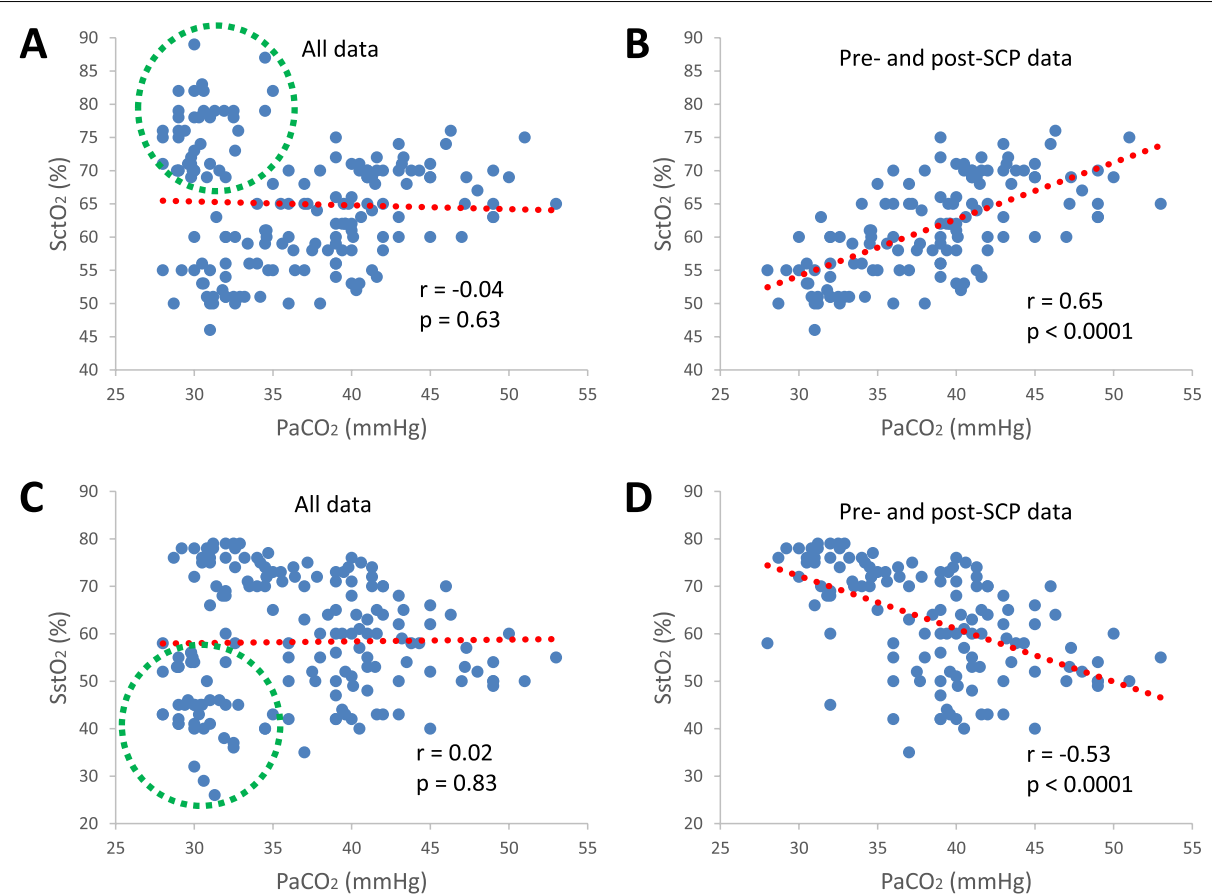

Fig. 4 Correlations between arterial blood carbon dioxidepartial pressure $\left(\mathrm{PaCO}_{2}\right)$ and cerebral tissue oxygen saturation $\left(\mathrm{SctO}_{2}\right)(\mathbf{A}$ and $\mathbf{B})$ and between $\mathrm{PaCO}_{2}$ and somatic tissue oxygen saturation $\left(\mathrm{SstO}_{2}\right)(\mathbf{C}$ and $\mathbf{D})$. The correlations were based on all data $(\mathbf{A}$ and $\mathbf{C})$ and data with the measurements during selective cerebral perfusion (SCP)excluded ( $\mathbf{B}$ and $\mathbf{D}$ ), respectively. The red dotted lines are trend lines and thedata points in green dotted circles are measurements during SCP

investigated the clinical application of the same multisite monitoring protocol in 26 pediatric patients $(11$ neonates, 5 infants, and 10 children) undergoing aortic coarctation repair [14]. They reported that the decline in $\mathrm{SstO}_{2}$ during aortic cross-clamping was larger in neonates and infants than children, which was attributed to a better established collateral circulation around the incomplete aortic obstruction in older patients. However, they did not specifically compare $\mathrm{SctO}_{2}$ and $\mathrm{SstO}_{2}$ at different time points and correlate $\mathrm{SctO}_{2} / \mathrm{SstO}_{2}$ with different physiological parameters.

The significantly lower $\mathrm{SstO}_{2}$, compared with $\mathrm{SctO}_{2}$, before aortic opening reflects the hypoperfusion of the tissue beds that were perfused by the vasculature distal to the aortic stenosis. The start of CPB led to simultaneous decreases of both $\mathrm{SctO}_{2}$ and $\mathrm{SstO}_{2}$, likely secondary to decreased global tissue oxygen delivery (delivery $=$ flow"hemoglobin*arterial blood oxygen saturation) assuming tissue oxygen consumption remained unchanged. The start of SCP led to a distinct increase of $\mathrm{SctO}_{2}$ while a decrease of $\mathrm{SstO}_{2}$, which reflects the effectiveness of SCP in increasing cerebral oxygen delivery and the corresponding worsening of peripheral oxygen delivery. The discrepancy between $\mathrm{SctO}_{2}$ and $\mathrm{SstO}_{2}$ was lessened toward the end of SCP, which was likely secondary to the adjustment of regional vascular resistance and flow redistribution. The aortic opening led to a remarkable increase of $\mathrm{SstO}_{2}$ while a remarkable decrease of $\mathrm{SctO}_{2}$, a distinct change in the oxygenation pattern that is likely caused by the hyperperfusion of the distal tissue beds and the simultaneous relative hypoperfusion (or a "steal" phenomenon) of the proximal tissue beds (in relevance to the aortic stenosis). The remarkable $\mathrm{SctO}_{2}$ decrease may also relate to the rewarming-related increase in cerebral tissue oxygen consumption. The discrepancy between $\mathrm{SstO}_{2}$ and $\mathrm{SctO}_{2}$ was gradually minimized thereafter which is likely, again, secondary to the adjustment of the vascular resistance of different tissue beds over time.

The consistent correlation between leg MAP and $\mathrm{SstO}_{2}$ reflects the chronic vasodilation and pressurepassive flow in the tissue beds that are perfused by the vasculature distal to the aortic stenosis. The confounding of the correlation between arm MAP and $\mathrm{SctO}_{2}$ by the measurements during SCP reflects the overriding effect of SCP on cerebral perfusion [15]. The sloped and linear relationship between arm MAP and $\mathrm{SctO}_{2}$ may be a reflection of the loss of cerebral autoregulation in this patient population undergoing the described type of open cardiac surgery $[9,16]$.

$\mathrm{SctO}_{2}$ positively correlated with $\mathrm{PaCO}_{2}$, while $\mathrm{SstO}_{2}$ negatively correlated with $\mathrm{PaCO}_{2}$ when the 
measurements during SCP are excluded (not included), which again highlights the following: (1) carbon dioxide is a predominantly cerebral vasodilator and hypercapnia leads to increased cerebral perfusion, (2) SCP has an overriding effect on cerebral perfusion, and (3) the correlations between $\mathrm{SctO}_{2} / \mathrm{SstO}_{2}$ and $\mathrm{PaCO}_{2}$ are confounded during SCP.

Our study demonstrated a significant correlation between $\mathrm{SctO}_{2}$ and $\mathrm{SmvO}_{2}$, which is supported by some previous reports [17] and refuted by others [18]. We also showed that $\mathrm{SctO}_{2}$ is more consistently correlated with $\mathrm{SmvO}_{2}$ than $\mathrm{SstO}_{2}$. Tissue oxygen saturation is tissue bed specific and measures the hemoglobin saturation of mixed arterial, capillary, and venous blood, while $\mathrm{SmvO}_{2}$ is the hemoglobin saturation of the pooled venous blood coming from a variety of tissue beds. These two parameters are different but related. The stronger correlation of $\mathrm{SctO}_{2}$, compared with $\mathrm{SstO}_{2}$, with $\mathrm{SmvO}_{2}$ reflects the dominance of cerebral metabolism and the dominant contribution of cerebral venous blood to the mixed venous blood in this patient population.

Our study has limitations that highlight the need for future studies. One of the important goals of a clinical monitor is to improve patient outcome via monitorguided care. This is normally done based on randomized controlled trials to understand if the proposed monitor-guided intervention is better than the conventional approach. In order to do so, an interventional protocol needs to be first established. An intervention protocol needs to specify the tissue dys-oxygenation thresholds beyond which corrective measures need to be instituted. It also needs to establish the intervention algorithm with details of when and how to intervene and the priorities, especially considering that tissue oxygenation is determined by multiple yet integrated variables. However, our study neither specifically studied the intervention guided by $\mathrm{SctO}_{2} / \mathrm{SstO}_{2}$ monitoring nor correlated $\mathrm{SctO}_{2} /$ $\mathrm{SstO}_{2}$ measurements with patient outcomes. In addition, future studies need to address the tissue beds that should be prioritized for monitoring and the details of intervention based on multisite monitoring. The sample size of our study is small. Large-scale studies are needed to validate our findings, establish the intervention protocol, and prove the outcome benefits.

\section{Conclusions}

In summary, $\mathrm{SctO}_{2}$ and $\mathrm{SstO}_{2}$ have distinct patterns of change during neonate and infant aortic coarctation repair. $\mathrm{SctO}_{2}$ and $\mathrm{SstO}_{2}$ measurements are surgical stage dependent. The correlations of tissue oxygenation with MAP and $\mathrm{PaCO}_{2}$ are confounded during SCP. The distinct changes in $\mathrm{SctO}_{2}$ and $\mathrm{SstO}_{2}$ and their correlations with MAP and $\mathrm{PaCO}_{2}$ suggests the potential value of multisite tissue oxygenation monitoring during high-risk pediatric cardiac surgeries.

\begin{abstract}
Abbreviations
COA: Coarctation of the aorta; CPB: Cardiopulmonary bypass; MAP: Mean arterial pressure; NIRS: Near-infrared spectroscopy; $\mathrm{PaCO}_{2}$ : Arterial blood carbon dioxide tension; PDA: Patent ductus arteriosus; SCP: Selective cerebral perfusion; $\mathrm{SctO}_{2}$ : Cerebral and tissue oxygen saturation; $\mathrm{SstO}_{2}$ : Somatic and tissue oxygen saturation; $\mathrm{SmvO}_{2}$ : Mixed venous blood oxygen saturation.
\end{abstract}

\section{Acknowledgements}

We thank the support and resources provided by the departments and institutions where the authors work.

\section{Authors' contributions}

L Zhang: conceptualization, methodology, data collection and checking, interpretation of data, writing original draft preparation. L Liu, ZQ Zhong: data collection and checking, interpretation of data, reviewing original draft preparation. HF Jin, J Jia: interpretation of data, statistical analysis, reviewing original draft preparation. L Meng: conceptualization, methodology, data collection and checking, interpretation of data, writing original draft preparation. XM Mo: interpretation of data, reviewing original draft preparation. XH Shi: conceptualization, methodology, interpretation of data, statistical analysis, reviewing original draft preparation. All authors read and approved the final manuscript.

\section{Funding}

This work was supported by the Jiangsu Province "Six Peak Talent" project (WSW-084, to L Zhang) and departmental resources at Nanjing Medical

University and Yale University.

\section{Availability of data and materials}

All data generated or analysed during this study are included in this published article and its supplementary information files.

\section{Declarations}

Ethics approval and consent to participate

This prospective cohort study was approved by the Institutional Ethics Committee of.

Children's Hospital of Nanjing Medical University with approval number 201501003-1. The.

patient's guardian provided verbal consent. All methods were carried out in accordance with Declaration of Helsinki.

\section{Consent for publication}

Not Applicable.

\section{Competing interests}

Lingzhong Meng received lecture fees from the previous CAS Medical Systems, Inc (now acquired by Edwards Lifesciences). The other authors declare no conflicts of interest.

Received: 26 May 2021 Accepted: 31 October 2021

Published online: 15 November 2021

References

1. Reller MD, Strickland MJ, Riehle-Colarusso T, et al. Prevalence of congenital heart defects in metropolitan Atlanta, 1998-2005. J Pediatr. 2008;153:807-13

2. Bjornard K, Riehle-Colarusso T, Gilboa SM, et al. Patterns in the prevalence of congenital heart defects, metropolitan Atlanta, 1978 to 2005. Birth Defects Res A Clin Mol Teratol. 2013;97:87-94.

3. Hoffman Jl, Kaplan S. The incidence of congenital heart disease. J Am Coll Cardiol. 2002;39:1890-900. 
4. Liang CD, Su WJ, Chung HT, et al. Balloon angioplasty for native coarctation of the aorta in neonates and infants with congestive heart failure. Pediatr Neonatol. 2009;50:152-7.

5. Cowley CG, Orsmond GS, Feola P, et al. Long-term, randomized comparison of balloon angioplasty and surgery for native coarctation of the aorta in childhood. Circulation. 2005;111:3453-6.

6. Brouwer RM, Erasmus ME, Ebels T, et al. Influence of age on survival, late hypertension, and recoarctation in elective aortic coarctation repair. Including long-term results after elective aortic coarctation repair with a follow-up from 25 to 44 years. J Thorac Cardiovasc Surg. 1994;108:525-31.

7. Lerberg DB, Hardesty RL, Siewers RD, et al. Coarctation of the aorta in infants and children: 25 years of experience. Ann Thoracic Surgery. 1982:33:159-70.

8. Bickler P, Feiner J, Rollins M, et al. Tissue Oximetry and Clinical Outcomes. Anesthesia Analgesia. 2017;124:72-82.

9. Meng L, Gelb AW, McDonagh DL. Changes in cerebral tissue oxygen saturation during anaesthetic-induced hypotension: an interpretation based on neurovascular coupling and cerebral autoregulation. Anaesthesia. 2013;68:736-41.

10. Berendes JN, Bredee JJ, Schipperheyn JJ, et al. Mechanisms of spinal cord injury after cross-clamping of the descending thoracic aorta. Circulation. 1982;66:1112-6.

11. Keen G. Spinal cord damage and operations for coarctation of the aorta: aetiology, practice, and prospects. Thorax. 1987;42:11-8.

12. Gelman S. The pathophysiology of aortic cross-clamping and unclamping. Anesthesiology. 1995;82:1026-60.
13. Hoffman GM, Stuth EA, Jaquiss RD, et al. Changes in cerebral and somatic oxygenation during stage 1 palliation of hypoplastic left heart syndrome using continuous regional cerebral perfusion. J Thorac Cardiovasc Surg. 2004; 127:223-33.

14. Berens RJ, Stuth EA, Robertson FA, et al. Near infrared spectroscopy monitoring during pediatric aortic coarctation repair. Paediatr Anaesth. 2006;16:777-81.

15. Meng L, Hou W, Chui J, et al. Cardiac Output and Cerebral Blood Flow: The Integrated Regulation of Brain Perfusion in Adult Humans. Anesthesiology. 2015;123:1198-208.

16. Meng L, Gelb AW. Regulation of cerebral autoregulation by carbon dioxide. Anesthesiology. 2015;122:196-205.

17. Weiss M, Dullenkopf A, Kolarova A, et al. Near-infrared spectroscopic cerebral oxygenation reading in neonates and infants is associated with central venous oxygen saturation. Paediatr Anaesth. 2005;15:102-9.

18. Redlin M, Koster A, Huebler M, et al. Regional differences in tissue oxygenation during cardiopulmonary bypass for correction of congenital heart disease in neonates and small infants: relevance of near-infrared spectroscopy. J Thorac Cardiovasc Surg. 2008;136:962-7.

\section{Publisher's Note}

Springer Nature remains neutral with regard to jurisdictional claims in published maps and institutional affiliations.
Ready to submit your research? Choose BMC and benefit from:

- fast, convenient online submission

- thorough peer review by experienced researchers in your field

- rapid publication on acceptance

- support for research data, including large and complex data types

- gold Open Access which fosters wider collaboration and increased citations

- maximum visibility for your research: over 100M website views per year

At BMC, research is always in progress.

Learn more biomedcentral.com/submissions 